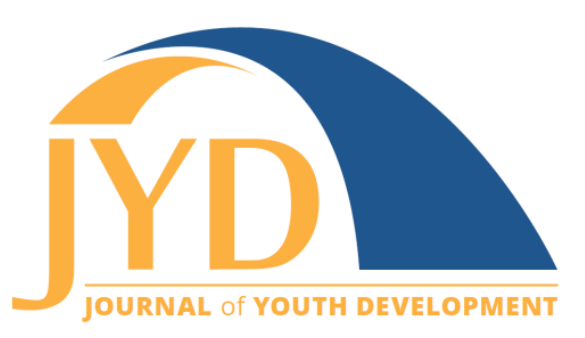

http://jyd. pitt. edu/ | Vol. 13 Issue 4 DOI 10.5195/jyd.2018.650 | ISSN 2325-4017 (online)

\title{
Moving Beyond Where and When to the People and Practices That Impact Youth
}

\section{Karen Pittman}

The Forum for Youth Investment

karen@forumfyi.org

\begin{abstract}
Descriptors like after-school and out-of-school make it easy for funders and families to understand the basics of what the youth development field offers-places for young people to go when they are not in school. These descriptors, however, do little to promote the youth work profession. Youth work is best practiced in settings that prioritize relationships, promote social and community engagement, and provide opportunities for interest-based skill building and exploration. The value youth workers bring to their practice, as the archive of articles in this journal demonstrates, is not in the basic descriptors of the setting, but in the design of the learning environments. This article explores the need for youth work professionals to use, contribute to, and share our knowledge base within and outside of the field.
\end{abstract}

Key words: youth work, after-school, practitioners, researchers

Over the past few years, I've increased the frequency and volume of my drum-banging, hoping to catapult the after-school and youth development fields into a discussion about our future. I am delighted to have the opportunity to beat the drum one more time, this time with a direct focus on practitioners and researchers who are deeply engaged in promoting the profession.

The JYD archives contain over 500 articles on youth work practice across a range of topics (e.g., youth-adult partnerships, youth work supervision, social justice and youth work, youth work knowledge models, police as youth workers). This is an incredible resource that should be contributed to and utilized by anyone who works with youth or youth workers, directly or indirectly. But I fear its potential is not fully utilized for three reasons:

(c) EY New articles in this journal are licensed under a Creative Commons Attribution 4.0 License. This journal is published by the University Library System, University of Pittsburgh and is cosponsored by the University of Pittsburgh Press. The Journal of Youth Development is the official peer-reviewed publication of the National Association of Extension 4-H Agents and the National AfterSchool Association. 
First, while we have made good progress, we need to find even more ways to get professionals who are practitioners as well as others working in the profession to reflect on and write about what they do and how we should or could be improving our craft. The Journal is a great start. I applaud the National Association of Extension 4-H Agents and the National AfterSchool Association for creating the journal and, even more important, making its contents so accessible. We have some ways to go, however, to strengthen the appetite for formal knowledge building, systematic categorization and effective sharing within our profession. I use workshops at national conferences (including the Forum's) as a barometer for measuring our progress on this front. While often extremely valuable to those in the sessions, the ideas, frameworks and findings presented are rarely grounded in the context of other work with corroborating citations or formally documented in peer review publications. We need to both lower barriers and raise expectations on this front. We cannot grow as a professional if we rely solely or primarily on presentations-especially ones neither grounded in nor contributing to the written body of knowledge needed to advance our work.

Second, while we have made great strides in promoting the important role after-school and youth development programs can play in young people's lives, especially in the lives of youth from families, schools and communities with limited resources, I fear that we have slipped backwards in our efforts to promote the profession. Youth work is best practiced in settings that prioritize relationships, promote social and community engagement, and provide opportunities for interest-based skill building and issue-based exploration. These criteria are often found in after-school and youth development programs. Over the past decade, however, the growth and purpose of these programs has been tied more to the fact that these programs should be where children and youth go when they leave school than to the fact that children and youth need access to adults who understand how learning and development happens and who provide rich opportunities for them to choose what they explore and master. I pulled up the table of contents of a random JYD issue (Vol. 8, No. 2, 2013). The four program articles included make my point well:

- Environmental Service and Outdoor Adventure as a Context for Positive Youth Development: An Evaluation of the Crow River Trail Guards Program by Julie Ernst and Jessamy Schwartz

- Social Justice and Civic Engagement through Participation in a Youth Health Leadership Program by Marie J. Bryant, Corliss Outley, and Michael B. Edwards

- Working Toward Peace: A Holistic Approach to Addressing Youth Violence by Pleasant Hill Baptist Church by Joann E. Lee, Miniard Culpepper, and Rhona Julien

- Take an Adventure Bite by Brian Brandt and Christina Murray 


\section{Advancing the Next Generation of Youth Work}

From the titles alone, it is clear that each article explores how youth work principles and practices can be utilized to increase youth engagement and skill-building in a different program setting, with the setting defined as some combination of place (e.g., outdoors, church), program type, issue or focus (e.g., health, social justice, youth violence, leadership, service, adventure). Describing these and other programs with generic terms like after-school, summer, and youth programming provides those inside and outside the field with easily memorable descriptors. Unfortunately, these descriptors mask the intentionality and diversity of what we do and, consequently, mask the importance and unique contributions of the profession we are trying to strengthen.

Third, and perhaps most importantly, I fear that we have inadvertently created a demand that others will now try to fill without using the wisdom we have gained over many years of practice. Calls for extended learning and expanded learning have, by and large, increased opportunities to partner with schools to create more and better learning opportunities for children and youth. These calls, however, have often led to transactional partnerships with schools that are consistent with the depiction of after-school and youth development organizations as "where/when" solution providers. As the call for better integration of social and emotional learning into the school building and school day takes hold, however, I fear (in fact I know) that $\mathrm{K}-12$ leaders are not looking to our field for advice. I would like to say that this is because K-12 leaders (including researchers and curriculum and training developers) believe that the differences between the K-12 and out-of-school-time systems (e.g., bureaucracy, pedagogy, accountability) limit the applicability of our research and practice base. My concern, however, is that we are simply not seen as knowledge partners because they do not know that our research exists and could and should inform their practice.

As an aging thought leader whose written work, so I'm told, has influenced the ways we think about ourselves and our work, I am re-upping my commitment to not only contribute to the professional vitality of the youth work field but also help bring it into the peripheral vision of other fields, including but not limited to health and K-12 education. I have used the last decade to help demonstrate, through the work and staff of the Weikart Center for Youth Program Quality, that good practice is measurable, malleable, and marketable in out-of-school programs. We can and should do more to ensure that after-school and youth organizations are places where good developmental practice happens. We must also, however, begin to do more to demonstrate that these practices (and professionals who use them) are transferable to all of the settings in which youth spend their time. The first step towards this is to do more to 
Journal of Youth Development | http://jyd.pitt.edu/ | Vol. 13 Issue 4 DOI 10.5195/jyd.2018.650

Advancing the Next Generation of Youth Work

demonstrate, document, and disseminate the value of what we do-and the why and how we do it and can do it better.

I will use the next decade to beat this drum loudly. I hope you will join me.

\section{References}

Brandt, B., \& Murray, C. (2013). Take an adventure bite. Journal of Youth Development 8(2), 96-105. doi:10.5195/jyd.2013.99

Bryant, M. J., Outley, C., \& Edwards, M. B. (2013). Social justice and civic engagement through participation in a youth health leadership program. Journal of Youth Development 8(2), 76-83. doi:10.5195/jyd.2013.97

Ernst, J., \& Schwartz, J. (2013). Environmental service and outdoor adventure as a context for positive youth development: An evaluation of the Crow River Trail Guards program. Journal of Youth Development 8(2), 57-75. doi:10.5195/jyd.2013.96

Lee, J. E., Culpepper, M., \& Julien, R. (2013). Working toward peace: A holistic approach to addressing youth violence by Pleasant Hill Baptist Church. Journal of Youth Development 8(2), 84-95. doi:10.5195/jyd.2013.98 